ROCZNIKI KULTUROZNAWCZE

Tom X, numer $4 \quad-\quad 2019$

DOI: http://dx.doi.org/10.18290/rkult.2019.10.4-3

\title{
SEBASTIAN MISIUK
}

\section{WYSTRASZYĆ I ROZBAWIĆ: MEDIATYZACJA EMOCJI W HEADACH RADIOWYCH SERWISÓW INFORMACYJNYCH}

Główną funkcją radiowych serwisów informacyjnych jest informowanie. $\mathrm{Ta}, \mathrm{z}$ pozoru oczywista, funkcja, polegająca z założenia na przekazaniu obiektywnych faktów, obecnie realizowana jest $\mathrm{z}$ wykorzystaniem rozmaitych środków przyciągających uwagę słuchacza. Współczesny odbiorca, z jednej strony aktywny, z drugiej rozproszony i przestymulowany, to z perspektywy mediów trudny klient, domagający się coraz silniejszych bodźców, coraz bardziej szokujących informacji oraz zaskakujących form ich przekazywania. Aby osiągnąć ten cel, nadawcy medialni wykorzystują rozmaite gry językowe, w tym grę na emocjach, za której sprawą informacja często przekształca się w komentarz, który Maria Wojtak nazywa „informacją zinterpretowaną" .

Celem niniejszego artykułu jest analiza radiowych serwisów informacyjnych pod kątem występowania przekazów nacechowanych emocjonalnie oraz próba odpowiedzi na pytania, w jaki sposób tego typu komunikaty oddziałują na odbiorcę i jak mogą być przez niego interpretowane. Zebrany materiał pozwala postawić hipotezę, że nadawcy medialni, a w tym przypadku rozgłośnie radiowe, wykorzystują emocjonalizację treści po to, by zatrzymać uwagę odbiorcy. Najczęściej sięgają po emocje negatywne, które mogą wzbudzać w słuchaczach strach, złość lub niepokój.

Media prawdopodobnie już na stałe zrezygnowały z przekazów czysto informacyjnych, takich, w których nadawca nie ma żadnych intencji wpły-

Sebastian MisiuK - Uniwersytet Warszawski, Wydział Polonistyki; adres do korespondencji — e-mail: misiuk.sebastian@gmail.com. ORCID: https://orcid.org/0000-0003-4034-7941.

${ }^{1}$ Maria WoJTAK, Gatunki prasowe (Lublin: Wydawnictwo Uniwersytetu Marii Curie-Skłodowskiej, 2004), 168-201. 
wania na postawy i zachowania odbiorców². Jak zauważa Krzysztof Kaszewski, takie komunikaty są sprzeczne $\mathrm{z}$ naturą człowieka, ograniczają jego indywidualną subiektywność ${ }^{3}$. Kwestią nierozwiązywalną pozostaje subiektywność nadawcy. W idealnym modelu informowania przekaz informacyjny, a więc obraz rzeczywistości, powinien być pozbawiony jakichkolwiek elementów osobistego filtra nadawcy. Czy jednak taka sytuacja jest możliwa? Biorąc za przykład analizowane $\mathrm{w}$ tym artykule radiowe serwisy informacyjne, można zaryzykować stwierdzenie, że nie jest możliwa. Już na etapie tworzenia serwisu informacyjnego, czyli decydowania o jego treściowej zawartości, odnajdujemy pierwsze ślady braku obiektywności nadawcy. Dziennikarz musi bowiem zadecydować, które tematy wykorzystać w serwisie, a które pominąć; które podać na początku, a które zostawić na koniec. Z powodu dość krótkiej formy serwisów nadawca musi także podjąć decyzję, które elementy danego tematu są (jego zdaniem) najważniejsze, a które mniej istotne. W końcu równie istotny jest dobór środków językowych, który ostatecznie może przyczynić się do braku obiektywności w przekazie medialnym, choć to właśnie kategoria obiektywności, w świadomości odbiorcy, pozostaje najważniejszym wyznacznikiem medialnego przekazu informacyjnego ${ }^{4}$. Być może należałoby zastąpić ją kategorią rzetelności, którą (rozwijając jedną z maksym konwersacyjnych Grice’a, maksymę jakości) można by określić jako przedstawianie wyłącznie tego, co według nadawcy jest zgodne z rzeczywistością ${ }^{5}$.

Kolejnym zjawiskiem potwierdzającym zerwanie z ideą czystego przekazu informacyjnego jest mieszanie przez nadawców podstawowych funkcji komunikatów - informacyjnej, perswazyjnej i rozrywkowej. To z kolei łączy się z kategorią punktu widzenia, niezwykle istotną w świecie wolnego rynku mediów. Jak wspomniałem na początku, nadawcy, a uściślając w tym przypadku - stacje radiowe, muszą walczyć o pozyskiwanie nowych lub pozostanie stałych słuchaczy. Nie mogłyby tego zrobić bez wzięcia pod uwagę potrzeb, jakie mają ich odbiorcy. Ci z kolei, mając dostęp do sze-

\footnotetext{
${ }^{2}$ Bogusława DoBeK-OstrowsKA, Podstawy komunikowania społecznego (Wrocław: Astrum, 1999), 32

${ }^{3}$ Krzysztof KASZEWSKI, Media o sobie. Językowe elementy autopromocyjne w przekazach informacyjnych prasy, radia i telewizji (Warszawa: Wydawnictwo Naukowe Semper, 2018), 20.

${ }^{4} \mathrm{O}$ pakcie faktograficznym, swoistej umowie między nadawcą i odbiorcą, pisał Zbigniew Bauer: „by była to umowa ważna — nadawca musi dochować kilku warunków, wśród których najważniejsze to: wierność przedstawianemu faktowi lub stanowi rzeczy, a także szczegółowość i zwięzłość”. Zbigniew BAUER, „Gatunki dziennikarskie”, w: Dziennikarstwo i świat mediów, red. Zbigniew Bauer \& Edward Chudziński (Kraków: Universitas, 2000), 143-173.

${ }^{5}$ KASZEWSKI, Media o sobie, 29.
} 
rokiej gamy produktów medialnych, wykorzystują rozgłośnie radiowe na swój sposób: po to, by uzyskać informację (wiedzę), czerpać przyjemność (rozrywkę), kształtować poczucie tożsamości lub dążyć do integracji ze swoją grupą społeczną ${ }^{6}$.

W związku z powyższym informowanie przestaje być nadrzędnym celem mediów. Na równi z nim, a czasem nawet ponad, stawiane jest dążenie do dostarczenia rozrywki lub utwierdzenia w konkretnych poglądach i pielęgnowanie określonych wartości, do czego wykorzystywana może być perswazja, a nawet manipulacja. Ponadto współczesne media masowe, podążając za swoim odbiorcą, przedstawicielem społeczeństwa informacyjnego, zabiegają o interakcję. To zaś, jak pisze Danuta Kępa-Figura, ,implikuje obniżenie poziomu oficjalności i związane z tym określone ukształtowanie formalnosemantyczne"

Jak zatem oddziaływać na współczesnego odbiorcę - słuchacza, by spełnić jego oczekiwania, a zarazem zrealizować swój cel? Jednym ze sposobów jest sięganie do pierwotnych instynktów - wywoływanie w odbiorcy emocji, pobudzających do wyraźnego wartościowania o charakterze negatywnym lub pozytywnym. W rezultacie można wymusić na nim ustosunkowanie się do prezentowanych zdarzeń i rzeczywistości ${ }^{8}$. Gra na emocjach, jak i wykorzystanie innych gier językowych czy słownych służy bowiem intensyfikacji procesów myślowych i emocjonalnych adresata wypowiedzi ${ }^{9}$.

Skoro mowa o grze na emocjach, należy zaznaczyć, że w literaturze przedmiotu istnieje wiele różnorodnych podejść do emocji, a co za tym idzie wiele różnych klasyfikacji. Na potrzeby niniejszego opracowania wystarczy przyjąć, że emocje to specyficzne reakcje na specyficzne wydarzenia. W odróżnieniu od nastrojów są zwykle krótkotrwałe i stosunkowo intensywne ${ }^{10}$. Psychologowie wyróżniają cztery obiektywne sytuacje, w których emocje zachodzą. Są to: zagrożenie, ograniczenie, pozbawienie i zaspokojenie. Wartość emocji jest zależna od znaczenia przedmiotu, zjawiska czy sytuacji dla osoby jej doświadczającej. W ten sposób można wyróżnić emocje pozytywne — kiedy przedmiot zakłócający równowagę zaspokaja potrzebę, i emocje

\footnotetext{
${ }^{6}$ Ibid., 25.

${ }^{7}$ Danuta KęPA-Figura, „Gry językowe we współczesnej komunikacji medialnej — semantyczna i pragmatyczna analiza języka mediów”. Prace Językoznawcze 11 (2009): 98.

${ }^{8}$ Stanisław MichalczYK, „Kognicje i emocje w procesie recepcji mediów”, Rocznik Prasoznawczy 11 (2017): 24.

${ }^{9}$ KęPA-Figura, „Gry językowe we współczesnej komunikacji medialnej”, 95-113.

${ }^{10}$ Richard J. Gerring \& Philip G. ZIMBARdo, Psychologia $i$ życie, przeł. Józef Radzicki, Ewa Czerniawska i in. (Warszawa: Wydawnictwo Naukowe PWN, 2011), 386.
} 
negatywne - kiedy przedmiot zakłócający równowagę stanowi zagrożenie. Emocje pozytywne są przyjemne, a negatywne - nieprzyjemne ${ }^{11}$. Taki nieco uproszczony podział wydaje się wystarczający na potrzeby podjętej tu analizy, albowiem istotniejsza jest w tym wypadku perspektywa mediolingwistyczna, a nie psychologiczna.

Dotychczasowe badania przekazów medialnych pod kątem emocjonalności w zasadzie nie skupiają się ani na radiowych serwisach informacyjnych, ani na samych headach. Ogólnej analizy emocjonalizacji treści medialnych dokonał Stanisław Michalczyk ${ }^{12}$, który zaznacza, że niemożliwe jest jednoznaczne określenie, w jaki sposób dany komunikat wpływa na odbiorcę. Uzależnione jest to od jego wiedzy, postaw, nastrojów i doświadczeń. Michalczyk powołuje się też na Dolfa Zillmanna, który już pod koniec lat 80. XX wieku zauważył, że regulacja nastrojów i emocji jest główną funkcją mediów w konsumpcyjnych i zindustrializowanych społeczeństwach Zacho$\mathrm{du}^{13}$. Odpowiedzi zatem na pytania o to, czy i w jaki sposób media wywołują emocje w odbiorcach, można udzielić w ujęciu bardzo ogólnym, z uwzględnieniem wielu płaszczyzn. Media mogą dostarczać emocji i odbiorca może być tego świadomy, co pozwala mu podejmować decyzje o wyborze mediów: zgodzić się na charakterystyczny przekaz danego nadawcy i z nim pozostać lub odrzucić go i wybrać innego. Media mogą wywoływać emocje, ale odbiorca nie jest tego świadomy, co sprzyja perswazji i manipulacji. Media próbują wywoływać emocje i odnoszą sukces lub trafiają na oporny grunt i ich intencje są ignorowane. W końcu mediom nie udaje się wywoływanie emocji, a produkowane przez nie przekazy stają się przerysowane. Warianty można mnożyć. W artykule przedstawiam propozycję interpretacji sytuacji, w której odbiorca jest podatny na wpływy nadawcy medialnego. Językowa analiza konkretnych przykładów nie wyczerpuje wszystkich strategii komunikacyjnych wykorzystywanych przez nadawców. Obszerną grupę problemów stanowi indywidualność odbioru przekazu medialnego, ale też aspekty środowiskowe i kulturowe tego procesu.

Analizowany przeze mnie korpus to 378 headów, czyli krótkich zapowiedzi radiowego serwisu informacyjnego, podawanych przed nim samym, mających przekonać słuchacza do pozostania przy radioodbiorniku oraz zatrzymywania uwagi na przekazywanej treści. W niniejszym opracowaniu

\footnotetext{
${ }^{11}$ Włodzimierz SzEwCZuK, „Emocje”, w: Encyklopedia psychologii (Warszawa: Fundacja Innowacja, 1998), 85-91.

12 MichalCZYK, „Kognicje i emocje”, 11-31.

${ }^{13}$ Ibid.
} 
skupię się na „Wiadomościach Radia ZET”, emitowanych od 6 do 11 maja 2019 r.

Radio ZET — to stacja o zasięgu ogólnopolskim, kierująca swój program do dorosłych Polaków. W okresie od marca do maja 2019 r., czyli w okresie, z którego pochodzi materiał badawczy, Radio ZET było na drugim miejscu wśród stacji ogólnopolskich, najchętniej wybieranych przez słuchaczy w wieku 15-75 lat, uzyskując 12,2\% słuchalności ${ }^{14}$. Każdego dnia stacja prezentuje 18 wydań serwisów informacyjnych poprzedzonych headami, składającymi się z zapowiedzi trzech najciekawszych lub najważniejszych wiadomości, które pojawią się w serwisie. W podjętej analizie skupiam się wyłącznie na headach, ponieważ to właśnie w nich kreatywność językowa redaktorów jest najbardziej widoczna. Ten element serwisu informacyjnego, swego rodzaju nagłówek, może pełnić funkcje deskryptywną i pragmatyczną. Zgodnie z typologią zaproponowaną przez Urszulę Żydek-Bednarczuk pierwsza ma moc „charakteryzującą i informującą o zawartości tekstu” ${ }^{15}$, druga — „reklamową, propagandową, emocjonalną, społeczną, stylistyczną" ". Zadaniami funkcji pragmatycznej nagłówków (headów) jest oddziaływanie na odbiorcę oraz skłanianie do określonej interpretacji i odrzucanie innych. Aby sprostać tym celom, dziennikarze stosują rozmaite chwyty, często odwołując się do emocjonalności potencjalnego odbiorcy.

Radio, ze względu na ulotność przekazu, sprzyja tego typu grom językowym. Szybkie tempo nadawanych komunikatów oraz fakt, że jest to medium zazwyczaj jedynie towarzyszące, wymusza zastosowanie środków „budzących” odbiorcę, poruszających jego ciekawość. Gwałtowność emocji może przejawiać się w jednym słowie lub wynikać z implikatur ukrytych w grach językowych (zjawiskach, których znaczenia nie wynikają wprost ze znaczeń użytych słów). W związku z tym wizja świata przedstawionego jest mniej związana z rzeczywistością i faktami, a bardziej z założonymi przez nadawcę oczekiwaniami odbiorcy. Nadawca mówi tak, jak — w jego mniemaniu - chciałby tego odbiorca.

Analizując zgromadzony materiał, korzystam z metodologii badań wypracowanej na gruncie językoznawstwa pragmatycznego. Głównym kryterium interpretacji będzie odczytanie implikatur konwersacyjnych powsta-

\footnotetext{
${ }^{14}$ Michał KURDUPSKI, „Radio ZET i Trójka z największymi spadkami, RMF FM liderem słuchalności”, dostęp 29.03.2020, https://www.wirtualnemedia.pl/artykul/radio-wyniki-sluchalnoscimarzec-maj-2019-rmf-fm-liderem.

${ }^{15}$ Urszula ŻYDEK-BEDNARCZUK, Wprowadzenie do lingwistycznej analizy tekstu (Kraków: Universitas, 2005), 173.

${ }^{16}$ Ibid.
} 
jących w wyniku celowego łamania przez nadawcę maksym, wynikających z teorii koncepcji kooperacji uczestników konwersacji Paula Grice'a ${ }^{17}$.

Przyjrzyjmy się przykładom. Wydaje się, że najbardziej reprezentatywnym dowodem wywoływania emocji u słuchacza, w celu zainteresowania go treścią serwisu informacyjnego, jest mówienie o wypadkach, katastrofach lub krwawych zdarzeniach. W środowisku dziennikarskim nie bez powodu krąży powiedzenie: „tylko złe wiadomości są dobrymi wiadomościami”. W badanym przeze mnie materiale przykładów takich headów jest kilkadziesiąt.

1. Komenda Główna Policji podsumowuje majówkę: zginęło mniej osób niż w zeszłym roku, ale to wciąż tragicznie dużo. Wciąż plagą są pijani kierowcy ${ }^{18}$.

2. Do czterdziestu jeden wzrosła liczba ofiar pożaru rosyjskiego samolotu w Moskwie $[\ldots]$.

3. Pijany dwudziestoczterolatek, który w Nysie uciekał przed policją i o mało nie rozjechał funkcjonariuszy, był niepoczytalny. Będzie wniosek o umieszczenie go w zakładzie zamkniętym.

4. Kolejna śmierć na szpitalnym oddziale ratunkowym. Nie żyje młody mężczyzna, pacjent szpitala w Świdnicy.

5. Tragedia na autostradzie A1. W pożarze ciężarówki spłonął koń szwedzkiej medalistki olimpijskiej.

6. Trwa dramat zakładników w Blagnac we Francji. Uzbrojony siedemnastolatek przetrzymuje w sklepie cztery kobiety.

7. Dwoje dzieci zginęło w Japonii. W grupę przedszkolaków wjechało rozpędzone auto $[\ldots]$.

8. Prezydent Warszawy deklaruje pomoc w sprawie tragedii w szkole w Wawrze. Jeden z uczniów śmiertelnie dźgnął ostrym narzędziem kolegę.

9. Ta tragedia wstrząsnęła pilską szkołą [...].

10. Dwoje dzieci wypadło z okna w Wolsztynie. Jedno z nich nie żyje.

11. Piętnastolatek zginął od ciosu nożem. Tragiczny finał nocnego spotkania w Lublinie.

12. Tragiczny wypadek w Pucku. Niespełna dwuletni chłopiec wypadł z okna. To kolejny już taki przypadek w ostatnim czasie.

13. Groźny wypadek na zakręcie śmierci w Bielsku Białej. Osobówka wjechała w radiowóz, trzy osoby trafiły do szpitala.

14. Trzy ciała ze śladami kuszy w hotelu. Tajemnicza śmierć w Niemczech.

\footnotetext{
${ }^{17}$ Herbert Paul GRICE, Logika a konwersacja, w: Język w świetle nauki, red. Barbara Stanosz (Warszawa: Czytelnik, 1980), 91.

${ }^{18}$ Wszystkie podane przeze mnie przykłady są zapisane dokładnie w takiej formie, w jakiej usłyszał je słuchacz na antenie.
} 
W wielu powyższych przykładach pojawia się przymiotnik „tragiczny”, którego słownikowa definicja brzmi: „budzący uczucie grozy i rozpaczy; naznaczony nieszczęściem"19. To słowo jednoznacznie może wywoływać u odbiorcy również poczucie niepokoju. W przypadku pierwszego przykładu, dotyczącego podsumowania majówki na drogach, na początku otrzymujemy informację pozytywną — ofiar wypadków było mniej, na drogach jest bezpiecznie. Dalsza część heada podkreśla jednak, że wciąż ta liczba jest duża, w związku z tym słuchacze nie mogą czuć się bezpiecznie, zwłaszcza że „wciąż plagą są pijani kierowcy”. Sformułowanie implikuje, że problem jest poważny, groźny i trudny do rozwiązania, a organy, które powinny sobie z nim poradzić, pozostają bezradne. W innych przykładach (5., 9. i 12.) ten sam znaczeniowo wyraz — ,tragedia" (w formach rzeczownikowej i przymiotnikowej) rozpoczyna całe wypowiedzenie, już na wstępie wywołując w słuchaczu niepokój. Forma rzeczownikowa (8., 9.) określa daną sytuację jako bardzo złą, taką, w której nie chcielibyśmy się znaleźć, buduje obraz świata, z góry naddany słuchaczowi, pozbawiając go możliwości oceny zdarzenia. Podobną funkcję może pełnić wyraz „dramat” czy konstrukcja „groźny wypadek". Wymienione leksemy są używane wyjątkowo często, ponieważ — jak można domniemywać — są skutecznym sposobem przyciągania uwagi. Odbiorca może poczuć niepokój, dlatego zdecyduje się wysłuchać serwisu informacyjnego do końca, by poznać szczegóły, być może poczuje także współczucie wobec ofiar zdarzenia. W końcu silne uderzenie emocji skupi jego uwagę na treści, wywołując strach o samego siebie.

W tej kategorii headów widoczna jest również obrazowość i szczegółowość. Na podstawie przykładu 14. słuchacz łatwo może zrekonstruować w wyobraźni obraz trzech ofiar z ranami ciała. Informacja o użytym w zbrodni narzędziu — kuszy — wprowadza element tajemniczości, co zgrabnie wykorzystuje dziennikarz w dalszej części wypowiedzi. To kolejny aspekt przyciągający uwagę słuchacza i każący mu pozostać przy radioodbiorniku dłużej, w nadziei na uspokojenie emocji lub ich zintensyfikowanie. Eksponowanie wieku uczestników opisywanych zdarzeń może mieć na celu wywołanie u odbiorcy złości połączonej z poczuciem niesprawiedliwości: śmierć młodego pacjenta, uzbrojony siedemnastolatek, grupa przedszkolaków jako ofiary zamachu, uczeń atakujący kolegę nożem czy dzieci, które wypadły $\mathrm{z}$ okna. Zwróćmy także uwagę na sam fakt pojawiania się tego typu informacji w headach. $Z$ jakiegoś powodu dziennikarze uważają, że są one istotne

\footnotetext{
${ }^{19}$ Hasło: „tragiczny”, Słownik języka polskiego PWN, dostęp: 29.03.2020, https://sjp.pwn.pl/ szukaj/tragiczny.
} 
i mogą przyciągnąć uwagę słuchacza, mimo że często nie dotyczą go bezpośrednio, a nawet dzieją się poza jego krajem.

Kolejna reprezentatywna grupa headów, wpływających na emocje odbiorców, dotyczy strajków lub protestów. Tego typu informacje pojawiają się w serwisach informacyjnych niemal każdego $\mathrm{z}$ siedmiu badanych przeze mnie dni. Oto przykłady ich zapowiedzi:

1. Pracownicy Poczty Polskiej zaczynają dziś protest. Walczą o pięćset złotych podwyżki. Do pracy pójdą w żółtych kamizelkach.

2. Rusza protest fizjoterapeutów. Posłuchajcie, co to oznacza dla pacjentów.

3. Maj bez fizjoterapeutów. Dziś rusza ich akcja protestacyjna. Domagają się obiecanych im podwyżek.

4. Kolejne grupy protestują, walcząc o podwyżki. Fizjoterapeuci dziś oddają krew, a pracownicy sądów i prokuratur rozbili namioty przed resortem sprawiedliwości.

5. Rodzice kontra Skarb Państwa. Kilkadziesiąt osób skarży państwo za strajk nauczycieli, bo znając zagrożenie, nie zapobiegli protestowi.

6. Protest rezydentów znów wisi w powietrzu. Czują się oszukani projektem ustawy o zawodzie lekarza.

7. Rezydenci oburzeni słowami Konstantego Radziwiłła wypowiedzianymi w Radiu ZET. Posłuchajcie, o co poszło.

Samo określenie „protest” jest nacechowane negatywnie. Rozumiane jako „ostre wystąpienie przeciw działaniu uważanemu za niesłuszne" ${ }^{20}$ zawsze oznacza niezgodę na czyjąś krzywdę. Z różnych powodów może wywoływać w odbiorcach między innymi złość, na przykład na nieudolność rządu. Fizjoterapeuci, rezydenci, nauczyciele czy pracownicy sądów i prokuratur muszą protestować, ponieważ rząd nie jest w stanie zaoferować im lepszych warunków pracy lub wyższych wynagrodzeń. Dodatkowo często podkreślany jest fakt, że owa pomoc rządu wcześniej była obiecana (3., 6.). Złość odbiorcy może wynikać także ze związanych z protestem utrudnień. W kontekście protestu fizjoterapeutów dziennikarze sami podsycają niepewność i złość, implikując, że akcja dotknie także obywateli (2.), i to przez cały miesiąc (3.). W tym przypadku obok złości możemy umieścić strach, na przykład o własne zdrowie. Protest to także konflikt między stronami, który dziennikarze bardzo chętnie podkreślają (5., 6., 7.). Sformułowanie „rodzice kontra Skarb Państwa" może implikować atmosferę sportowej walki, mocny atak, odpowiedź na silne uderzenie. Rezydenci czują się oszukani przez ustawodawcę

\footnotetext{
${ }^{20}$ Hasło: ,protest”, Słownik języka polskiego PWN, dostęp 29.03.2020, https://sjp.pwn.pl/ sjp/protest.
} 
i są oburzeni słowami ministra zdrowia. Takie odczucie potęgują wykorzystywane często czasowniki „walczyć” oraz „domagać się”. Silna polaryzacja w tych krótkich zapowiedziach kolejny raz podsycona jest dozą tajemniczości. Dziennikarze, celowo łamiąc maksymę ilości, nie mówią wszystkiego, zachęcając do wysłuchania wiadomości w celu poznania szczegółów. Intensyfikacja tego typu komunikatów może poprzez implikatury wywoływać w odbiorcy poczucie niepokoju związanego z niestabilnością kraju, niesprawiedliwością i zagrożeniem własnego bezpieczeństwa.

Dużą część serwisów informacyjnych, a co za tym idzie — także headów zajmuje w badanym materiale polityka. Ten specyficzny temat może wywoływać emocje już z powodu samego faktu pojawienia się w komunikacie. Odbiorca może być nastawiony negatywnie do wszystkiego, co polityczne, lub wręcz przeciwnie - wybierając konkretną stację i znając jej profil polityczny, oczekiwać potwierdzenia swoich przekonań, co daje dziennikarzom spore pole do gier językowych.

1. W sejmie grillowanie Grzegorza Schetyny. Szef PO nie ma wątpliwości, że jego przesłuchanie przed komisją VAT-owską to kampania PiS-u.

2. Jarosław Sellin w Radiu ZET o maturach i fałszywych alarmach bombowych: były dziwne oczekiwania części strajkujących nauczycieli, żeby egzaminy się nie udały. W „Wiadomościach” zastrzega: ja tych dwóch rzeczy nie łączę.

3. W Wiadomościach także o milionerach z Brukseli. Europosłowie z Polski nieźle dorobili się na kadencji, która właśnie się kończy.

4. „Nie chcemy władcy, pana, a tym bardziej króla z dworem” — Grzegorz Schetyna na konwencji w Płocku o konieczności pożegnania obecnego rządu.

W tych przypadkach powszechne jest używanie cytatów lub mowy zależnej. Dziennikarze wybierają najmocniejsze fragmenty wypowiedzi polityków, podgrzewając często atmosferę konfliktu. Słuchacz może również odnieść wrażenie, jakoby nadawca aprobował stanowisko polityka, co najbardziej widoczne jest w przykładach $\mathrm{z}$ wykorzystaniem mowy zależnej (1. i 2.). Przyjrzyjmy się również kolejności podawanych informacji w obrębie heada nr 2. Najpierw słuchacz dowiaduje się, jakoby Jarosław Sellin łączył strajk nauczycieli z alarmami bombowymi. Dopiero w drugiej części tego komunikatu dziennikarz prostuje tę wypowiedź, uzupełniając ją o kolejne zdanie. Taka kolejność — w przypadku dosyć ulotnego medium, jakim jest radio - może zakrawać na manipulację, chęć wpłynięcia na poglądy słuchacza. Podobnie jest w przypadku ostatniego przykładu z tej grupy. Cytat wypowiedzi Grzegorza Schetyny, podany na samym początku tego komunikatu, może bardzo mocno oddziaływać na odbiorcę, zwłaszcza tego, który ma zbliżone poglądy polityczne. 
Warto w tym miejscu zwrócić uwagę na silnie negatywnie nacechowany rzeczownik ,grillowanie” użyty w przykładzie 1. Bohater opisywanego wydarzenia występuje tu $\mathrm{w}$ roli ofiary. W potocznym i metaforycznym znaczeniu chodzi zapewne o postawienie Grzegorza Schetyny w ogniu pytań dociekliwych oponentów politycznych, wielogodzinne przedłużające się przesłuchanie dotyczące wielu aspektów sprawy, niepozbawione uszczypliwych komentarzy i zarzutów.

Ladunek emocjonalny zwarty jest także w przykładzie 3., który może wywołać w odbiorcy złość. Mamy tu do czynienia z tematem zarobków. W pierwszym zdaniu heada dziennikarz od razu nazywa europosłów milionerami z Brukseli. Milioner dla przeciętnego słuchacza jest osobą niedostępną, reprezentującą pewnego rodzaju elitę oddaloną od niego zwłaszcza w kwestii zrozumienia jego problemów życia codziennego. Dziennikarz, używając czasownika „dorobić się”, poprzedzonego przysłówkiem „nieźle”, wykorzystuje ironię, implikując tym samym nowe znaczenie tych słów. W neutralnym, a zarazem potocznym znaczeniu dorobić się oznacza „osiągnąć coś dzięki swojemu staraniu"21. Słowem wzmacniającym potocyzm i ładunek emocjonalny jest przysłówek „nieźle”. W połączeniu takie określenie może być odczytane jako: znacznie wzbogacić się przy niewielkim nakładzie pracy. Dodatkowo taka konstrukcja implikuje opozycję my (zwykli ludzie) — oni (milionerzy z Brukseli), stawiając słuchacza na równi z dziennikarzem, zwykłym człowiekiem w kontrze do bogatej elity.

Kolejność informacji w zdaniu odgrywa ogromną rolę w nadawanym komunikacie. Najważniejsze i zapadające w pamięć odbiorcy są informacje podane na początku i na końcu. To, co w środku, staje się mniej istotne. Spójrzmy zatem na różne heady dotyczące tego samego tematu.

1. Skazany za podwójne morderstwo, niewinny mężczyzna, decyzją Sądu Najwyższego wychodzi na wolność. To druga taka sprawa, po słynnym przypadku Tomasza Komendy.

2. Arkadiusz Kraska zaczyna nowe życie. Skazany za podwójne morderstwo, prawdopodobnie niesłusznie, wychodzi z więzienia.

3. W Wiadomościach też pierwsze godziny na wolności Arkadiusza Kraski. Wyszedł z więzienia po dziewiętnastu latach odsiadki, prawdopodobnie niesłusznej.

4. - To nie była pomyłka, to była premedytacja - tak po wyjściu z więzienia mówił Arkadiusz Kraska. Prawdopodobnie niesłusznie odsiedział dziewiętnaście lat.

\footnotetext{
${ }^{21}$ Inny słownik języka polskiego PWN, red. Mirosław Bańko (Warszawa: Wydawnictwo Naukowe PWN, 2000).
} 
W przykładzie 1. dziennikarz, mówiąc o skazanym za podwójne morderstwo, wychodzi od informacji budzącej jednoznacznie negatywne emocje, dopiero po chwili tłumaczy słuchaczowi, że bohater informacji jest niewinny. Ten komunikat w całości może też wywoływać pozytywne emocje u odbiorcy — w końcu sprawiedliwość zwyciężyła i niewinny człowiek opuszcza mury więzienia. W każdym jednak z czterech przykładów odnoszących się do tego samego tematu mowa jest o nieudolności wymiaru sprawiedliwości (niewinny człowiek spędza w więzieniu kilkanaście lat), co może podawać w wątpliwość rzetelność przedstawicieli sądów, odpowiednich ministerstw, a nawet władz kraju. To zdecydowanie aspekt wywołujący złość, ale też strach (każdy może zostać skazany za czyn, którego nie popełnił).

Poprzez odwrócenie kolejności podawanych informacji head z przykładu 2. nabiera nieco innego wydźwięku. Na początku dowiadujemy się o szczęściu, jakie spotyka bohatera wydarzeń, zaczyna on bowiem nowe życie. Jednocześnie w tym przypadku nieudolna konstrukcja zdania może też implikować, że Arkadiusz Kraska z więzienia wychodzi prawdopodobnie niesłusznie. W radiu, w wersji audialnej, ta kwestia gramatyczna została rozwiązana za pomocą odpowiedniego akcentowania i pauzy między słowami „niesłusznie” oraz „wychodzi”. W przypadku przykładu 3. słuchacz zostaje wciągnięty bezpośrednio w wydarzenia, dostaje bowiem obietnicę, że za chwilę będzie towarzyszył w pierwszych godzinach bohatera informacji na wolności. W ostatnim przykładzie dziennikarze znów posiłkują się cytatem z bardzo silną oceną wymiaru sprawiedliwości, nacechowaną jednoznacznie negatywnie.

Kolejna wybrana przeze mnie grupa headów wydaje się tematycznie najbliżej słuchacza, ponieważ może dotyczyć spraw bezpośrednio z nim związanych. I w nich również przeważa negatywny ładunek emocjonalny.

1. Są problemy ze szczepionkami przeciwko gruźlicy. Sanepid zaleca, by szpitale oszczędnie stosowały te preparaty.

2. Niemcy kręcą bat na rodziców, którzy nie szczepią dzieci przeciwko odrze. Będą kary finansowe $\mathrm{i}$ to słone.

3. Odra atakuje. Zachorowali na nią osadzeni i pracownicy ośrodka dla bestii w Gostyninie. Zaraz szczegóły.

4. W Wiadomościach też raport aptekarskiego związku: brakuje leków refundowanych i fachowców w aptekach, co naraża zdrowie pacjentów.

5. Alarmujący raport naukowców - ludzie w zastraszającym tempie niszczą swoje środowisko.

6. Alarmujące dane także $\mathrm{w}$ innej dziedzinie - my, Polki stronimy od wizyt u ginekologa. Milion kobiet chodzi do takiego lekarza rzadziej niż raz w roku. 
7. My, ludzie doprowadziliśmy naszą planetę na skraj kompletnego zniszczenia. Jeszcze nigdy nie było tak źle - pokazuje to najnowszy raport ONZ.

8. Przerażające dane Eurostatu na temat Polski. Jesteśmy trzecim największym trucicielem środowiska spośród krajów Unii Europejskiej.

9. Możecie mieć problemy z ustaleniem, skąd pochodzą sprzedawane u nas warzywa i owoce. Zaraz raport na ten temat.

10. To będzie trudny weekend dla warszawskich kierowców. Posłuchajcie, co będzie się działo na drogach.

11. Wielkie emocje wokół zatrzymania kobiety, która rozkleiła plakaty z wizerunkiem Maryi z tęczową aureolą. Posłuchajcie, jak sprawę komentuje Donald Tusk.

12. Zupełnie niemajowy mamy maj. Uwaga! Tej nocy czekają nas przymrozki. Posłuchajcie, gdzie będzie najgorzej.

13. Rząd nie walczy ze smogiem tak, jak powinien. Polski Alarm Smogowy bije na alarm w tej sprawie.

W większości tych przykładów wiązka emocjonalna widoczna jest na pierwszy rzut oka. Poczucie niepokoju z powodu braku szczepionek i możliwości wystąpienia epidemii gruźlicy (1.) łączy się z poczuciem złości (przeciwnicy szczepionek) lub strachu, a nawet zadowolenia (zwolennicy szczepionek) w przypadku słonych kar za nieszczepienie dzieci w Niemczech (2.). I choć mowa jest o zjawisku za granicą, to jednak bardzo bliską, może więc ono wpłynąć także na zmiany w naszym kraju. Obawa przed utratą zdrowia jest w przykładzie 3. podsycona czasownikiem ,atakuje”. Widać tu szczególną chęć wywołania silnych emocji, albowiem tak mocne określenie zjawiska zaobserwowanego jedynie w jednym miejscu w kraju implikuje możliwość rozprzestrzenienia się choroby w szybkim tempie na resztę społeczeństwa. Podobnie jest w przykładzie 4., gdzie nadawca bezpośrednio wskazuje, że brak leków i fachowców w aptekach naraża pacjentów na niebezpieczeństwo.

Spójrzmy również na przykłady dotyczące raportów naukowców (5.-8.). Wielokrotnie pojawiają się tu nacechowane negatywnie przymiotniki „alarmujący” oraz „przerażający”. Odbiorca, po oczywistej sugestii nadawcy, jednoznacznie ocenia, że dane podawane przez specjalistów są dla niego niekorzystne, powinien więc albo zacząć się czegoś obawiać, albo złościć na kogoś, kto jest za taki stan rzeczy odpowiedzialny — zwłaszcza jeśli w dalszej części tych komunikatów pojawiają się takie określenia, jak: „zastraszające tempo”, „niszczyć”, „skraj kompletnego zniszczenia”, ,jeszcze nigdy nie było tak źle". Najmocniejsze uderzenie widzimy w przykładach 6.-8., gdzie dziennikarz wprost określa sprawców złej kondycji środowiska, uży- 
wając formy „my, ludzie” oraz ,jesteśmy największym trucicielem”, a w przypadku niechęci do badań ginekologicznych — „my, kobiety”. To wywołanie poczucia winy i współodpowiedzialności bardzo mocno może wpłynąć na postrzeganie świata przez odbiorcę.

Kolejny już dowód na wpływ komunikatów na emocje odbiorcy mogą stanowić przykłady z jawnymi przestrogami (9.-10.), typu: „możecie mieć problem” czy „to będzie trudny weekend”, lub bezpośrednio wskazujące kontrowersyjność komunikatu (11.): „wielkie emocje wokół” (tu także odwołanie do komentarza znanej postaci). Słuchacz już od początku ma świadomość, że musi przygotować się na coś, co będzie dla niego niekorzystne, niekomfortowe lub wywoła w nim silne emocje, w tym wypadku negatywne.

$\mathrm{Na}$ zakończenie analizy przekazów o zabarwieniu negatywnym spójrzmy jeszcze na podkreślające tę cechę gry słowne. Maj stereotypowo kojarzy się $\mathrm{w}$ kulturze polskiej jako miesiąc $\mathrm{z}$ temperaturami dodatnimi, pierwszym po zimie ciepłym podmuchem wiosny. W przykładzie 12. poprzez wykorzystanie neologizmu „niemajowy” nadawca uwypukla odmienny obraz tegorocznego maja, nieprzystający do tego zapisanego w świadomości odbiorcy - zimny, z ujemnymi temperaturami. Wykorzystanie wykrzyknienia „uwaga!” i ostrzeżenia przed przymrozkami jeszcze bardziej potęguje to odczucie. Nie bez powodu też dziennikarz zamiast określenia „najzimniej” używa przymiotnika „najgorzej”.

W ostatnim przykładzie z tej grupy (13.) dziennikarz wykorzystuje sugestywne powtórzenie, opierając się na danej już nazwie własnej organizacji. Polski Alarm Smogowy sam w sobie istnieje po to, by alarmować o konkretnym zjawisku. Nadawca, używając frazeologizmu „bić na alarm”, wzmacnia przekaz, co ma jeszcze bardziej zaniepokoić odbiorcę.

Choć w badanym materiale zdecydowaną większość stanowią heady o negatywnym zabarwieniu emocjonalnym, znajdziemy też informacje neutralne lub takie, które mogą wywołać u odbiorcy pozytywne uczucia. Przykładem może być tu grupa headów dotyczących matur.

1. Za dwie godziny zaczyna się egzamin dojrzałości. Maturzyści już wstali? Na początek obowiązkowy język polski.

2. Matury - czas start. Właśnie zaczyna się pisemny egzamin z języka polskiego.

3. Znamy tematy z matury z polskiego na poziomie podstawowym: maturzyści pisali egzamin między innymi z Dziadów Adama Mickiewicza. Posłuchajcie pierwszych gorących opinii tych, którzy właśnie skończyli. 
Tego typu informacje zazwyczaj traktowane są jako czysto informacyjne lub pozytywne, odwołujące się do czasów młodości, o ile dany odbiorca dobrze wspomina okres egzaminów dojrzałości. U niektórych słuchaczy może również wywoływać emocje negatywne, takie jak strach. Myślę tu o aktualnych maturzystach lub osobach, które mocno przeżywały ten okres w swoim życiu.

Znamiona pozytywnych emocji możemy znaleźć także w informacjach z grupy infotainment. W przypadku badanego materiału dotyczyły one między innymi narodzin dziecka brytyjskiej pary książęcej.

1. Brytyjczycy czekają na Royal Baby. Dziecko Meghan i Harry’ego może przyjść na świat lada moment.

2. Wielka radość na brytyjskim dworze królewskim. Księżna Meghan urodziła synka. Bukmacherzy przyjmują zakłady, jak będzie miał na imię.

3. Witam brata w klubie ludzi pozbawionych snu - książę William gratuluje Harry'emu narodzin syna.

4. A to życie po polityce. Michele i Barack Obama w rolach producentów filmowych. Wiemy już, co nakręcą dla Netflixa.

5. Za mundurem... sportowcy sznurem. Po tym, jak Mistrz Świata w skokach narciarskich ogłosił, że zostanie policjantem — sprawdzamy, kto jeszcze.

6. Będziemy też w Tatrach. Tam na świeżym śniegu można zobaczyć ślady niedźwiedzia.

7. Pomyślcie życzenie i wypowiedzcie je w Krakowie. W stawie na Plantach pojawiły się złote rybki.

W powyższych przykładach wykorzystano modyfikację powiedzenia „za mundurem panny sznurem" (5.). Tego typu gra słowna może być uznawana za zabawną, wywołującą pozytywny przekaz. Podobne funkcje mogą pełnić informacje dotyczące zwierząt (6.) oraz odniesienia do osadzonych kulturowo opowieści czy legend.

Pozytywne emocje mogą wywoływać informacje na pozór negatywne, mówiące o świecie przestępczym, piratach drogowych lub sytuacjach zagrażających życiu innych, ale wyłącznie wtedy, kiedy sprawcę takich wydarzeń dosięga zasłużona kara lub dana historia ma pozytywne zakończenie.

1. Pijany 24-latek, który w Nysie uciekał przed policją i o mało nie rozjechał funkcjonariuszy — decyzją sądu idzie do aresztu.

2. Skazany za podwójne morderstwo, niewinny mężczyzna, decyzją Sądu Najwyższego wychodzi na wolność. To druga taka sprawy, po słynnym przypadku Tomasza Komendy.

3. Arkadiusz Kraska zaczyna nowe życie. Skazany za podwójne morderstwo, prawdopodobnie niesłusznie, wychodzi z więzienia. 
Przykłady 2. i 3. były analizowane wcześniej. Dowodziłem tam, że mogą wywoływać emocje negatywne. Prezentowana jednak w nich historia to nic innego, jak szczęśliwe zakończenie wieloletniej udręki niewinnego człowieka, co samo w sobie zdaje się być informacją pozytywną.

Podobnym zabarwieniem charakteryzują się wszelkiego rodzaju informacje kulturalne, dotyczące konkursów i nagród, poradnikowe czy mówiące o kampaniach społecznych.

1. Wyjątkowy prezent na osiemnastkę przygotowała Unia Europejska. Można wygrać darmowy bilet na podróżowanie koleją po Europie.

2. Będzie też hasło: Łączy nas sport. W Gdańsku zachęcają trenerów, by dołączali do swoich drużyn osoby niepełnosprawne. O tej wyjątkowej kampanii za chwilę.

3. Będzie też o Katowicach, które dziś zakasały rękawy i sprzątają las.

4. Katowice znowu są jak Wyspy Kanaryjskie. Po zimowej przerwie na rynek wróciły cztery olbrzymie palmy.

5. Jedno dziecko - jedno drzewo. Na koniec niezwykła akcja w Katowicach.

6. Za chwilę też Stodki koniec dnia. Dziś premiera filmu Jacka Borcucha. Za rolę w nim Krystyna Janda została nagrodzona w Sundace.

7. Za chwilę też wiadomości kulturalne. A w nich o wspaniałym artyście, który dziś wystąpi w Polsce.

8. Za chwilę o tym, jak jeździć autem, by zaoszczędzić parę złotych na paliwie.

Do grupy pozytywnych można zaliczyć też informacje sportowe, choć uzależnione jest to od tego, czy słuchacz interesuje się sportem oraz którym drużynom kibicuje. Mimo wszystko można przyjąć, że niektóre informacje uznawane są za ogólnie pozytywne.

1. Ręce do braw składają się same. Liverpool pokonał Barcelonę 4:0 i jest w finale Ligi Mistrzów. O sensacyjnym pojedynku na Anfield usłyszycie w Sporcie po Wiadomościach.

2. Rafał Majka dobrze rozpoczął wyścig Giro d'Italia. Mimo że na czasówce w Bolonii stracił do zwycięzcy 33 sekundy [...].

W ostatniej grupie znalazły się heady, w których pojawia się jednoznaczne określenie, że prezentowane informacje są pozytywne. Te najczęściej dotyczą odbiorcy bezpośrednio. W przykładzie 1. odnoszą się do kraju, w którym słuchacz żyje, w przykładzie 2. pełnią funkcję poradnikową.

1. Polska zbiera pochwały. Jesteśmy drugim najszybciej rozwijającym się krajem w całej Unii Europejskiej.

2. W Wiadomościach mamy też dobre wieści dla tych, którzy nie mają czasu w tygodniu. Jutro macie szansę na załatwienie niektórych spraw urzędowych. 


\section{WNIOSKI}

W ocenie przekazów informacyjnych najważniejszy jest punkt widzenia odbiorcy. Ta sama wypowiedź, w zależności od tego, do kogo trafi, może zostać zinterpretowana $\mathrm{w}$ inny sposób. Zależy to od doświadczeń odbiorcy, jego przekonań, poglądów i wiedzy. Dlatego jednoznaczna kategoryzacja oraz dokładne określenie perlokucji jest w tym wypadku niemożliwe, tak jak niemożliwe jest zbadanie efektów wywołanych informacjami u wszystkich odbiorców. Podane przeze mnie oceny mogą stanowić jedynie punkt wyjścia do dalszych rozważań lub zarys możliwych interpretacji illokucji nadawców. Mimo to bardzo widoczny jest stosunek informacji o ewentualnym negatywnym zabarwieniu emocjonalnym do treści czysto informacyjnych lub nacechowanych pozytywnie. Pierwsza grupa jest najliczniejsza. W tym wypadku jednoznacznie możemy stwierdzić, czy przekaz jest negatywny czy pozytywny. W kolejnych to rozróżnienie staje się coraz trudniejsze i mniej precyzyjne.

Bez wątpienia można wymienić strategie, jakimi posługują się nadawcy, by wywołać u swoich odbiorców konkretne emocje. Są to przede wszystkim:

1) kategoria potoczności, wymuszająca rezygnację z wyszukanych konstrukcji językowych, odwołująca się do wiedzy i doświadczeń znanych przeciętnemu odbiorcy;

2) wykorzystywanie form podkreślających intensywność danych zjawisk, np. „kolejny”, „znów”, „wciąż”;

3) gry językowe, czyli użycie neologizmów słowotwórczych, modyfikacji nazw własnych lub modyfikacji frazemów;

4) łamanie maksym konwersacyjnych, najczęściej maksymy ilości poprzez wprowadzanie pierwiastka tajemniczości;

5) używanie powtórzeń oraz wyrazów o jednoznacznym i silnym nacechowaniu emocjonalnym;

6) obrazowość i szczegółowość w relacjonowaniu zdarzeń oraz przedstawianiu rzeczywistości;

7) wykorzystywanie wykrzyknień, takich jak „uwaga!”;

8) posługiwanie się cytatami wypowiedzi bohaterów zdarzeń lub przekształcanie ich w mowę zależną;

9) operowanie kolejnością w poszczególnych elementów — od bardziej szokujących do najmniej istotnych;

10) dobór tematyki prezentowanej w zapowiedziach serwisów: najczęściej zdarzenia nagłe, intrygujące i zaskakujące, od wypadków, przez politykę po infotainment. 
$\mathrm{Z}$ analizy materiału wynika, że w zapowiedziach radiowych serwisów informacyjnych częściej pojawiają się wiadomości uznawane powszechnie za negatywne. Nadawcom bez wątpienia udaje się wywołać w słuchaczach strach, złość i niepokój. Obecność takich emocji pozwala sądzić, że nacechowany przekaz staje się w pewnym sensie atrakcyjniejszy od przezroczystego. Można więc założyć, że odbiorca, który styka się z tego rodzaju komunikatem na etapie zapowiedzi serwisu informacyjnego, pozostanie przy radioodbiorniku, by dowiedzieć się więcej. Emocjonalizacja jednak prowadzi także do ograniczania odbiorcy na polu interpretacji treści, co - choć niebezpieczne - w dobie społeczeństwa przestymulowanego informacjami może okazać się kluczowe. Komunikat zawierający opinię silnie nacechowaną emocjonalnie naraża słuchacza na bezkrytyczne przyjęcie obrazu świata wykreowanego przez nadawcę.

Mimo że - jak pokazano - w przekazach medialnych dominują emocje negatywne, to od jakiegoś czasu tworzone są nowe marki, które rezygnują z podawania informacji złych, dotyczących sporów politycznych lub obfitujących w krwawe szczegóły. Za prekursora „,dziennikarstwa nadziei” (,journalism of hope” w kontrze do „bad news”) uważa się Allana Neuharta, który w 1987 r. założył dziennik USA Today. W jednym z wydań, w dniu katastrofy lotniczej, w której zginęło 57 osób, na pierwszej stronie widniał tytuł: „Cud: 327 osób przeżyło, 57 zginęło"22. Teoria Neuharta nie weszła do szerokiego obiegu. Najwięksi nadawcy wciąż częściej sięgają po informacje negatywne, tłumacząc, że tego właśnie oczekują odbiorcy. Z kolei odbiorcy nie protestują przeciwko temu masowo. Widać to również w samym układzie zarówno headów, jak i serwisów informacyjnych. W zdecydowanej większości wypadków dziennikarze rozpoczynają od informacji negatywnych. Jeśli decydują się na przekazanie informacji pozytywnej, pojawia się ona zazwyczaj w środku serwisu/headów lub na końcu.

Wszystko wskazuje więc na to, że taka strategia po prostu się sprawdza. Mimo powszechnej krytyki konstruowania negatywnej wizji świata, wzbudzanie emocji negatywnych najprawdopodobniej lepiej się sprzedaje, a media to przecież marketing.

\footnotetext{
${ }^{22}$ Marek CHYLIŃSKI \& Stephan Russ-MoHL, Dziennikarstwo (Warszawa: Grupa Wydawnicza Polskapresse, 2008), 129.
} 


\section{BIBLIOGRAFIA}

BAUER, Zbigniew. „Gatunki dziennikarskie”. W: Dziennikarstwo i świat mediów, red. Zbigniew Bauer \& Edward Chudziński, 143-173. Kraków: Universitas, 2000.

ChYliŃSKI, Marek, \& Stephan Russ-MoHL. Dziennikarstwo. Warszawa: Grupa Wydawnicza Polskapresse, 2008.

DobeK-Ostrowska, Bogusława. Podstawy komunikowania społecznego. Wrocław: Astrum, 1999.

Gerring, Richard J., \& Philip G. ZImbardo. Psychologia $i$ życie. Przełożyli Józef Radzicki, Ewa Czerniawska i in., Warszawa: Wydawnictwo Naukowe PWN, 2011.

Hasła: „tragiczny”, „protest”. Słownik języka polskiego PWN. Dostęp 29.03.2020. https://sjp.pwn.pl/ szukaj/tragiczny, https://sjp.pwn.pl/slowniki/protest.

Inny słownik języka polskiego PWN, red. Mirosław Bańko. Warszawa: Wydawnictwo Naukowe PWN, 2000.

KASZEWSKI, Krzysztof. Media o sobie. Językowe elementy autopromocyjne w przekazach informacyjnych prasy, radia i telewizji. Warszawa: Wydawnictwo Naukowe Semper, 2018.

KĘPA-FiguRA, Danuta. „Gry językowe we współczesnej komunikacji medialnej — semantyczna i pragmatyczna analiza języka mediów". Prace Językoznawcze 11 (2009): 95-113.

KURDUPSKI, Michał. „Radio ZET i Trójka z największymi spadkami, RMF FM liderem słuchalności”. Wirtualnemedia. Dostęp 29.03.2020. https://www.wirtualnemedia.pl/artykul/radiowyniki-sluchalnosci-marzec-maj-2019- rmf-fm-liderem.

MichAlCZYK, Stanisław. „Kognicje i emocje w procesie recepcji mediów”. Rocznik Prasoznawczy 11 (2017): 11-31.

SzEwCZuK, Włodzimierz. Encyklopedia psychologii. Warszawa: Fundacja Innowacja, 1998.

WoJTAK, Maria. Gatunki prasowe. Lublin: Wydawnictwo Uniwersytetu Marii Curie-Skłodowskiej, 2004.

ŻYDEK-BEDNARCZUK, Urszula. Wprowadzenie do lingwistycznej analizy tekstu. Kraków: Universitas, 2005 .

\section{WYSTRASZYĆ I ROZBAWIĆ: MEDIATYZACJA EMOCJI W HEADACH RADIOWYCH SERWISÓW INFORMACYJNYCH}

\section{Streszczenie}

Informacja radiowa, ze swej natury obiektywna, niesie za sobą często ogromny ładunek emocjonalny. Nadawcy, chcąc zatrzymać słuchacza, odwołują się do skrajnych emocji: na jednym biegunie za cel stawiają sobie wywołanie poczucia zaniepokojenia, na drugim próbują rozbawić odbiorcę lub dostarczyć mu rozrywki. Media bombardują doniesieniami dotyczącymi terroru, krwawych wypadków, sporów politycznych czy katastrof ekologicznych. Aby rozładować to napięcie, nadawcy sięgają po infotainment, informacje lekkie, zabawne, czasami wręcz infantylne. Najsilniej nacechowane emocjonalnie są heady zapowiadające serwisy informacyjne. I to właśnie te elementy serwisów informacyjnych Radia ZET z okresu od 6 do 12 maja 2019 r. stanowią materiał do analizy. Badania ilościowe pokazują, po które emocje nadawcy sięgają najczęściej, natomiast analiza jakościowa pozwoli przyjrzeć się środkom językowym wykorzystywanym do tego celu.

Słowa kluczowe: emocje; head; informacja radiowa; percepcja; radio. 


\section{TO FRIGHTEN AND TO AMUSE: \\ MEDIATISATION OF EMOTIONS \\ IN THE RADIO NEWS SECTION HEADINGS}

S u m m a r y

Seemingly objective radio-information sharing often exhibits a significant amount of emotional weight. Senders tend to invoke extreme emotions in order to rivet listeners' attention. On the one hand, they focus on the feeling of anxiety, however, on the other the primary goal is to amuse and entertain. Media bombards us with news regarding terror, bloody accidents, political disputes or ecological disasters. Senders often use infotainment - light-weight, humorous, and at times infantile information - to release the tension. The strongest emotional impact can be found in the news' headings. Aforementioned headings presented during the Radio ZET's broadcasts (for the period ranging from $6^{\text {th }}$ until $12^{\text {th }}$ of May 2019) construct the corpus on which the analysis is conducted. The quantitative research indicates which emotions are most frequently exploited, however the qualitative research allows for the further examination and analysis of stylistic devices used.

Key words: emotions; headings; perception; radio; radio information. 